\title{
Influence of cumulus cell coculture and cumulus- aided embryo transfer on embryonic development and pregnancy rates
}

\author{
Kumulus hücre kokültürünün ve kumulus destekli embryo transferinin embryonik \\ gelisim ve gebelik oranlanna etkisi
}

\author{
Nalan Cihangir ${ }^{1}$, Hüzeyin Görkemli ${ }^{1}$, Suna Özdemirr1, Murat Aktan², Selçuk Duman² \\ ${ }^{1}$ Department of Obstetrics and Gynecology, Meram Medical Faculty, Selcuk University, Konya, Turkey \\ ${ }^{2}$ Department of Histology and Embryolog, Meram Medical Faculty, Selcuk University, Konya, Turkey
}

\section{Abstract}

0 bjective: In this study, we aimed to evaluate the influence of autologous cumulus oocyte complex (COC) coculture on embryonic development and quality, and investigate the implantation and pregnancy rates after cumulus-aided embryo transfer in the ICSI-ET cycles.

Material and Methods: Ninety five consecutive infertile women undergoing their first cycle of IVF teratment were included in the study. The cases were divided into two groups. Group 1 consisted of 48 women undergoing ICSI, along with autologous cumulus embryo coculture and cumulus-aided emryo transfer. Group 2 comprised 47 consecutive patients who consented to undergo ICSI and in whom autologous cumulus embryo coculture and cumulus-aided embryo transfer were not performed. Implantation and pregnancy rates were compared between the two groups.

R esults: The demographic data and controlled ovarian hyperstimulation parameters were similar in the two groups. The fertilization and cleavage rates were found to be higher in group 1 when compared with group 2 ( $p=0.03$ and 0.001 , respectively). There were no statistical significant differences for the implantation and clinical pregnancy rates between the two groups.

Conclusion: Usage of autologous COCs as coculture may improve fertilization and cleavage rates. However, cumulus-aided embryo transfer does not produce an increase in implantation and pregnancy rates. (J Turkish-German Gynecol Assoc 2010; 11: 121-6)

Key words: Coculture, Cumulus cells, ICSI-embryo transfer, Pregnancy rate

Received: 9J uly, 2010

Accepted: 12 August, 2010

\section{Özet}

Amaç: Bu çalışmada, otolog kumulus-oosit kompleks (COC) kokültürünün embryonik gelişim ve kalitesine etkisini değerlendirmek, ve ICSI-ET sikluslannda kumulus destekli embryo transferinin implantasyon ve gebelik oranlanna etkisini araşırmayı amaçladık.

Gereç ve Yöntemler: Yardımla üreme tedavisinin ilk siklusunda olan 95 infertil kadın hasta çalışmaya dahil edildi. Vakalar iki alt gruba aynldı. Grupl otolog embryo kokültürü ve kumulus destekli embryo ttransferi uygulanan 48 hastay kapsadı. Diğer grup ise rutin ICSI tedavisi uygulanan 47 hastayı içerdi. Bu grupta otolog kumulus embryo kokültürü ve kumulus destekli embryo transferi uygulanmadı. İmplantasyon ve gebelik oranlan iki grup arasında karşılaştınldı.

Bulgular: Demografik veriler ve kontrollü ovarian hiperstimulasyon parametreleri her iki grup arasında benzerdi. Fertilizasyon ve yanklanma oranlan grupl'de grup 2'den istatiksel olarak anlamlı derecede yüksek saptandı (sırasıyla $p=0.03$ ve 0.001 ). İmplantasyon ve gebelik oranlan açısından her kik grup arasında istatiksel olarak anlamlı fark tespit edilmedi.

Sonuç: Otolog kumulus-oosit kompleksinin kokültür olarak kullanılması fertilizasyon ve yanklanma oranlannı arttrabilir. Bununla birlikte, kumulus destekli embryo transferi implantasyon ve gebelik oranlanna katkı sağlamamaktadır.

(J Turkish-German Gynecol Assoc 2010; 11: 121-6)

Anahtar kelimeler: Kokültür, Kumulus hücreleri, ICSI-embryo transfer, Gebelik oranı

Geliş Tarihi: 09 Temmuz 2010

Kabul Tarihi: 12 Ağustos 2010

\section{Introduction}

The concept of improved preimplantation development and implantation ability by coculturing embryos in the presence of another cell type called feeder cells has led to the development of the coculture system. A number of cell types have been used for this purpose. These feeder cells have included human reproductive tissues, such as oviducts, endometrium, oviduct-endometrial sequential coculture, cumulus-granulosa cells and even cells from ovarian carcinoma (1-7). The

suggested beneficial effects of cocultures were the secretion of embryotrophic factors such as nutrients and substrates, growth factors, and cytokines and the removal of potentially harmful substances including heavy metals, ammonium, and free radical formation, thus detoxifying the culture medium $(8,9)$. The main effect is to increase the metabolic chance of the human embryo to achieve the blastocyst stage and implant. However, the results concerning an actual increase of pregnancy rate on a large scale after the transfer of cocultured embryos in the uterus may be conflicting. There is also 
debate about usage of coculture or sequential culture media to obtain a large number of viable blastocysts.

Several studies have demonstrated faster cleavage rates, less fragmentation, and better implantation rates after using a coculture system $(7,10,11)$. It has been reported that the coculture system increased blastulation rates to $55 \%-70 \%(12,13)$. In most mammals, the oocyte in the Graafian follicle is surrounded by tightly packed layers of cumulus cells, forming the cumulusoocyte complex (COC). During the preovulatory period, cumulus cells change from a compact cell mass into a dispersed structure of cells for the synthesis and deposition of a mucoid intercellular matrix, a process referred to as cumulus expansion. Cumulus expansion is thought to influence a variety of fundamental developmental changes during oocyte maturation. Volumetric expansion of COC correlates, with the outcome of oocyte maturation, fertilization, and embryo development. It may be hypothesized that coculture of embryos with cumulus cells that serve as a source of growth factors would lead to an increase in the adhesiveness of embryos. However, there is limited data about the effects of COC coculture on embryonic development and pregnancy rates in the literature.

In this study, we aimed to evaluate the usage of autologous COC coculture as a medium for embryonic development and quality and also establish implantation and pregnancy rates after cumulus-aided embryo transfer in the ICSI-ET cycles.

\section{Material and Methods}

\section{Patient selection}

The present study was a prospective, single-centre, randomized, controlled, group-comparative clinical trial assessing cumulus coculture and cumulus-aided embryo transfer in women undergoing IVF. A total of 113 consecutive women who underwent ICSI-ET cycles at the Assisted Reproductive Unit of Meram Medical Faculty from January 2008 to February 2009 were included in this study. The flowchart for the study population is shown in Fig. 1. Randomized assignment of the two procedures was performed by a computer-based program. The sequence of allocation to the two groups was not concealed and the study was not blind. Patients could participate in the study only once. The study was approved by the Ethics Committee of Meram Medical Faculty and informed consent was obtained from all patients before entry into the study. Indications for ICSI-ET treatment included unexplained infertility, anovulation, male and tubal factors. Exclusion criteria were: presence of a clinically significant systemic disease; diabetes mellitus, polycystic ovaries or any other endocrine disorder and submucosal polyp, leio-myoma or uterine septum which were detected on hysteroscopy or hysterosalpingography.

The patients were divided into two groups - Group1 (study) consisting of 48 consecutive consenting patients who had undergone ICSI, along with autologous cumulus embryo coculture and cumulus-aided emryo transfer. Group 2 (control) comprised of 47 consecutive patients who consented to undergo ICSI without cumulus coculture and cumulus-aided embryo transfer.

\section{Stimulation protocol and preparing procedure}

All patients were started on $1 \mathrm{mg} /$ day Leuprolide acetate (Lucrin, Abbot, France) on the $21^{\text {st }}$ day prior to menstruation for pituitary desensitization. When exogenous gonadotropins were started in down-regulated women on day 2 of menstruation, the dose of Leuprolide acetate was decreased to $0.5 \mathrm{mg} /$ day. It was administered daily until the day of HCG injection. Initial mean doses of $177.5 \mathrm{IU}$ and $185 \mathrm{IU}$ recombinant FSH (recFSH, Gonal F, Serono, Italy) or human menopausal gonadotropin (hMG, Menogon, Ferring, Germany) were started on the second day of menstruation for 6 days. FSH dose was adjusted individually according to the response of the ovaries and estradiol concentrations. When the leading follicle reached $18 \mathrm{~mm}$ in diameter or at least two follicles were $>17 \mathrm{~mm}$ in diameter, a total of 10,000 units of HCG were administered intramuscularly. Oocyte retrieval was performed $35-37 \mathrm{~h}$ later by ultrasound-guided procedure.

After aspiration of COCs from the patient, whenever the collected COCs exceeded the $10 \mathrm{M}$ II stage after hyaluronidase treatment; the excess COCs were spared for usage. We continued the study in these patients with excess numbers, and the women with the spare COC of $\geq 4$ were included in the study group.

Group1 (study): After microinjection of $10 \mathrm{M}$ II stage oocytes was completed, they were placed into their droplets ( each 90 microliter Cleavage Medium, SAGE) as 2-3 oocytes per droplet, and for each of these droplets one COC was added and continued for embryo culture (5.0\% CO2, 99.9\% humidified). Whenever the embryos were changed to a new droplet, the COC was simultaneously carried. . During embryo transfer, the selected embryos were grouped in a medium pool (Blastocyst Medium supplemented with 30\% HSA SAGE) and the larger and intact COC was selected to add to the pool (Figure 2). Embryo loading to the catheter (Wallace, Smiths, England) was done as selected embryos plus COC in a 50-70 microliter medium (Figure 3). The contents of the catheter were released into the uterus over a period of 8-10 seconds, and the catheter was held in position for about 15 seconds. If the excess COC number was not enough the patient was excluded from the study.

Group 2 (control): The same stimulation protocol was administered and oocyte retrieval was performed 35-37 h later. After microinjection of $10 \mathrm{M}$ II stage oocytes was completed, they were placed into their droplets (each 75 microliter Cleavage Medium, SAGE) as 2-3 oocytes per droplet and continued for embryo culture without any COC addition. Culturing and embryo transfer technique was similar to groupl except for COC addition.

The luteal phase was supported with micronized vaginal progesterone, $600 \mathrm{mg} / \mathrm{day}$, up to the tenth week of gestation in cases where pregnancy was achieved. Clinical pregnancy was confirmed 28-35 days after embryo transfer by a the presence of a gestational sac on ultrasound.

\section{Sample size and statistical analysis}

The sample size was estimated on the basis of the expected implantation rate. The reported implantation rate in patients undergoing cumulus-aided embryo transfer is $25.6 \%$ (14). 


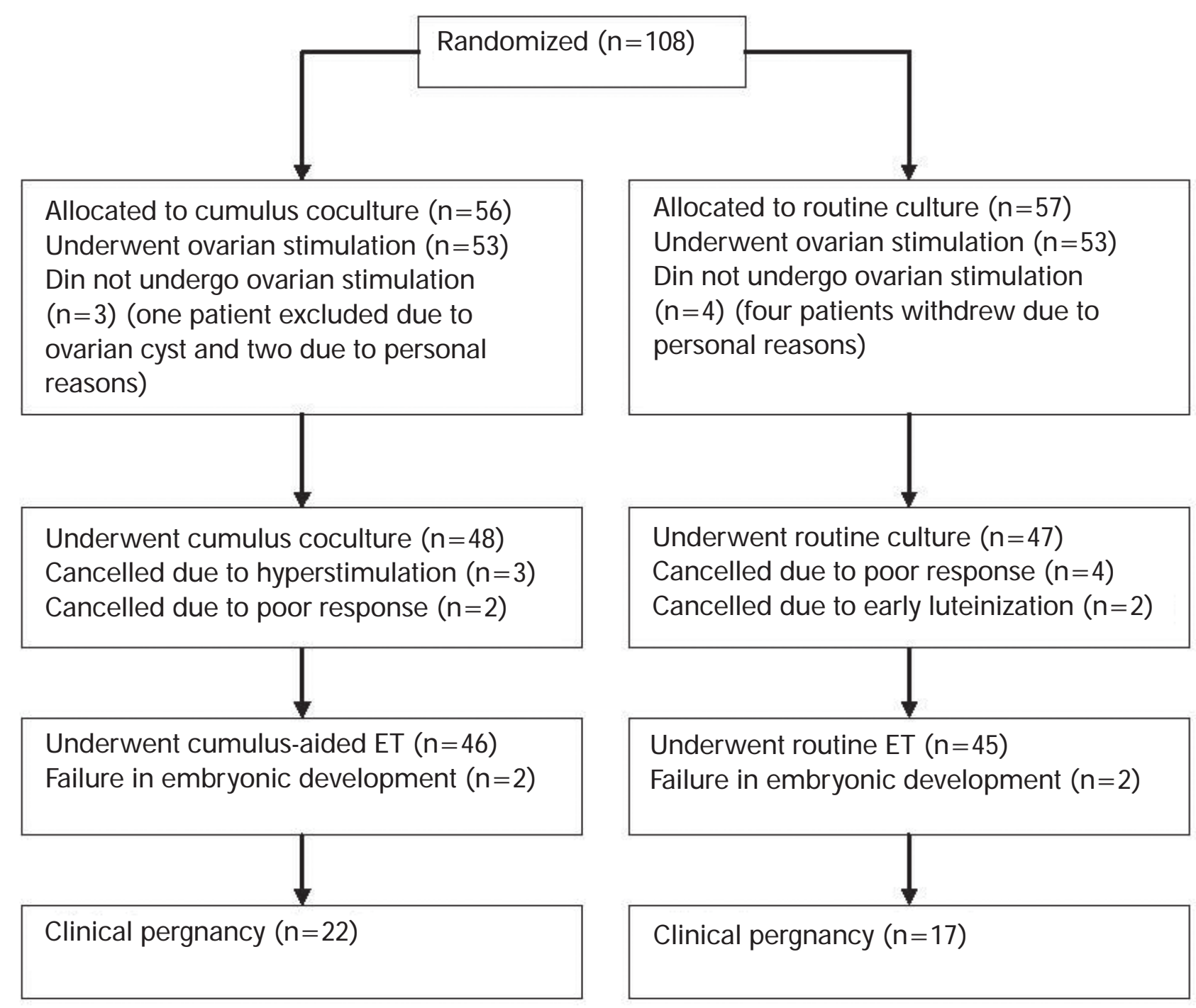

\section{Figure 1. Flowchart of the study population}

Assuming the implantation rate to be $5 \%$ different for women with cumulus-aided embryo transfer, 47 women in each group would be required to provide $80 \%$ power at the $5 \%$ significance level. Values were expressed as mean \pm SD for continuous variables and the number and percentage for categorical variables. The $\chi^{2}$ test and Student's test were used to compare categorical and parametric data, respectively. The nonparametric MannWhitney $U$ test was used to check for differences between numeric variables between the 2 groups. All $P$ values were 2-tailed and $\mathrm{P}<0.05$ was considered statistically significant.

\section{Results}

The demographic features of the study participantsare shown in Table 1. The mean ages, duration and causes of infertility (unexplained, anovulation, tubal and male factors) were similar in the two groups. The controlled ovarian hyperstimulation characteristics of both groups are listed in Table 2. The mean duration of stimulation, doses of daily administered recFSH, sum of recFSH doses, doses of daily administered HMG, sum of HMG doses, estradiol levels on hCG administration, endometrial thickness measured by transvaginal sonography on hCG administration day, mean number of oocytes at metaphase II stage (MII) per each cycle and total number of MII oocytes were similar in the two groups. There were no statistical significant differences between the study and control groups for cycle characteristics. The parameters of the wo groups after ICSI procedure are displayed in Table 2 . The fertilization and cleavage rates, total number of high quality embryos per transfer, numbers of embryos on day 2 and 3, mean number of embryos transferred, implantation rates and pregnancy rates were investigated after ICSI procedure. The fertilization rate was higher in Group 1 (study group) when compared with Group 2 (control group). The mean fertilization rates at $18-21$ hours in Groups 1 and 2 were $56.63 \%$ and $44.37 \%$, 
respectively (Table 3 ). There was a statistically significant difference between the two groups $(p=0.03)$ for this parameter. The cleavage rate was found as $59.6 \%$ in the study group, and it was detected as $41.4 \%$ in control group. Group 1 had a significantly higher cleavage rate than Group $2(p=0.001)$.

The total number of high quality embryos per transfer, numbers of embryos on day 2 and 3, t mean number of embryos transferred, implantation and pregnancy rates were similar in the two groups. Statistically significant differences were not obtained between the study and control groups. Although the study group had higher clinical pregnancy rate than the control group, a statistically significant difference was not determined between the two groups.

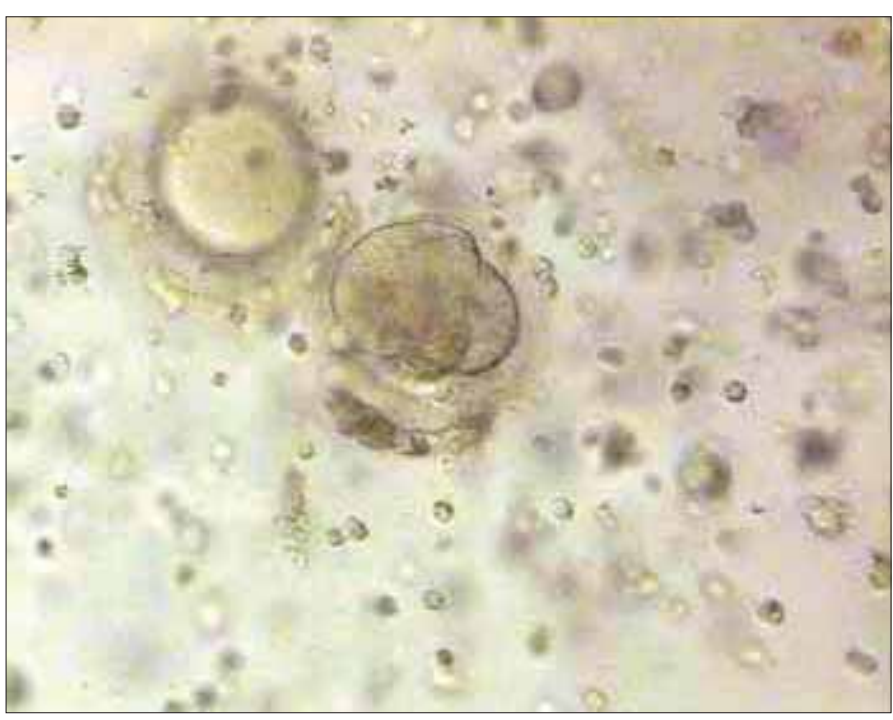

Figure 2. Two ICSI performed embryos inside COC at 26. hour, one without any progression while the other developed to the two blastomer stage

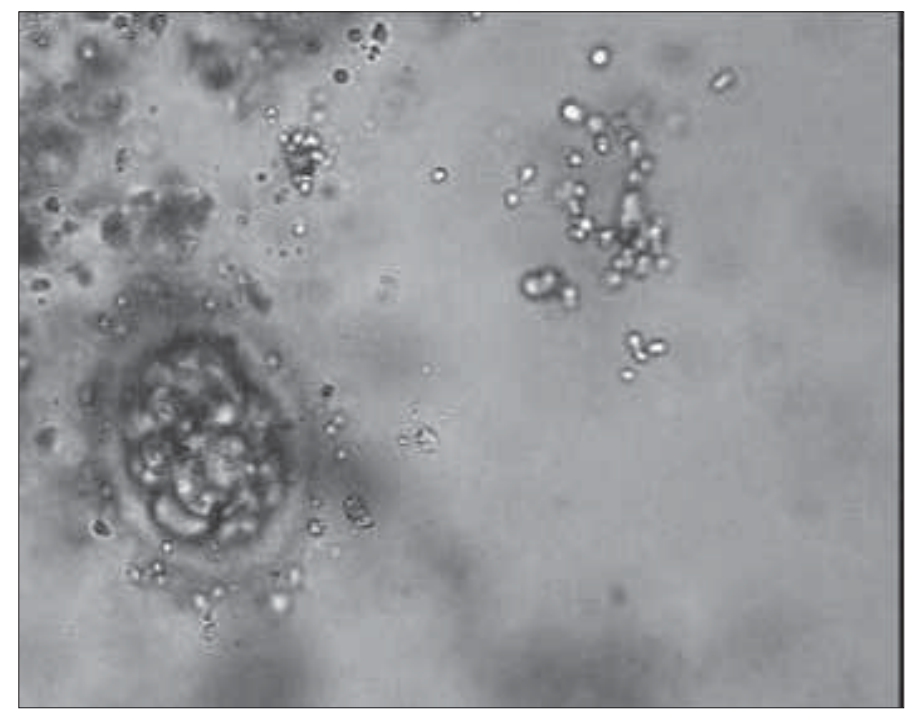

Figure 3. An early 4th. day embryo before embryo transfer, the embryo is embedded in COC. The embryo is suspended inside the matrix not touching the base of the culture dish which gives confluency to the image
Table 1. Demographic features of the groups

\begin{tabular}{|l|c|c|c|}
\hline & $\begin{array}{c}\text { Group 1 } \\
\text { (n= 48) }\end{array}$ & $\begin{array}{c}\text { G roup 2 } \\
\text { (n= 47) }\end{array}$ & $\begin{array}{c}\text { p } \\
\text { value }\end{array}$ \\
\hline Mean age (year) & $27.6 \pm 3.3$ & $28.8 \pm 4.4$ & 0.58 \\
\hline Infertility duration & $6.7 \pm 2.1$ & $5.8 \pm 2.8$ & 0.27 \\
\hline Infertility causes & \multicolumn{3}{|l}{} \\
\hline Unexplained & $17(35 \%)$ & $15(32 \%)$ & 0.74 \\
\hline Anovulation & $13(27 \%)$ & $14(30 \%)$ & 0.24 \\
\hline Tubal factor & $10(21 \%)$ & $11(23 \%)$ & 0.59 \\
\hline Male factor & $8(12 \%)$ & $7(15 \%)$ & 0.35 \\
\hline
\end{tabular}

Table 2. The ovarian hyperstimulation characteristics of both groups

\begin{tabular}{|l|c|c|c|}
\hline Parameter & $\begin{array}{c}\text { Group 1 } \\
\text { (n= 48) }\end{array}$ & $\begin{array}{c}\text { Group 2 } \\
\text { (n= 47) }\end{array}$ & $\begin{array}{c}\mathbf{p} \\
\text { value }\end{array}$ \\
\hline $\begin{array}{l}\text { Duration of } \\
\text { stimulation/day }\end{array}$ & $10.48 \pm 1$ & $10.52 \pm 1.1$ & 0.52 \\
\hline $\begin{array}{l}\text { Daily FSH } \\
\text { consumption (IU) }\end{array}$ & $177.5 \pm 37.2$ & $185 \pm 46.2$ & 0.17 \\
\hline $\begin{array}{l}\text { Total FSH } \\
\text { consumption (IU) }\end{array}$ & $1859.5 \pm 434.5$ & $1884.5 \pm 502.3$ & 0.74 \\
\hline $\begin{array}{l}\text { Daily HMG } \\
\text { consumption (IU) }\end{array}$ & $84 \pm 24.6$ & $78 \pm 14.8$ & 0.42 \\
\hline $\begin{array}{l}\text { Total HMG } \\
\text { consumption (IU) }\end{array}$ & $2737 \pm 435.6$ & $2697.5 \pm 539.3$ & 0.22 \\
\hline $\begin{array}{l}\text { Total FSH+HMG } \\
\text { consump. (IU) }\end{array}$ & $2210 \pm 369.3$ & $2166 \pm 425.5$ & 0.82 \\
\hline $\begin{array}{l}\text { Estradiol on hCG } \\
\text { day (pg/ml) }\end{array}$ & $10.7 \pm 1.7$ & $10.5 \pm 1.7$ & 0.52 \\
\hline $\begin{array}{l}\text { End. thickness on hCG } \\
\text { day (mm) }\end{array}$ & $12.3 \pm 1.6$ & $12.8 \pm 2.2$ & 0.44 \\
\hline Total MII oocytes (n) & $613 \pm 127.9$ & 0.64 \\
\hline M II oocyte per cycle (n) & 17517 & 0.51 \\
\hline
\end{tabular}

Table 3. The parameters of both groups after ICSI procedure

\begin{tabular}{|l|c|c|c|}
\hline Parameter & $\begin{array}{c}\text { G roup 1 } \\
(\mathbf{n = 5 0 )}\end{array}$ & $\begin{array}{c}\text { Group 2 } \\
(\mathbf{n = 5 0 )}\end{array}$ & $\begin{array}{c}\mathbf{p} \\
\text { value }\end{array}$ \\
\hline Fertilization rate (\%) & 56.6 & 44.3 & 0.03 \\
\hline Cleavage rate (\%) & 59.6 & 41.4 & 0.001 \\
\hline Total embryos (n) & 217 & 206 & 0.18 \\
\hline Embryos on day2 (n) & $31(62 \%)$ & $32(64 \%)$ & 0.53 \\
\hline Embryos on day3 (n) & $19(38 \%)$ & $18(36 \%)$ & 0.61 \\
\hline Embryos / transfer (n) & $2.8 \pm 0.5$ & $2.9 \pm 0.5$ & 0.27 \\
\hline Implantation rates (\%) & $34 \%$ & $33 \%$ & 0.46 \\
\hline Pregnancy rates (\%) & $22(46 \%)$ & $17(36 \%)$ & 0.09 \\
\hline
\end{tabular}




\section{D iscussion}

The use of another cell type for cocultures during IVF is currently finalized to obtain a high number of healthy and viable embryos with a high potential of implantation (14). Among the different cell lines that can be used as feeder cells for cocultures, COCs express some growth factors and cytokines, which are known to improve embryo morphology. There is little data about the effects of COCs coculture on human embryo development or pregnancy rates in IVF procedures. The present study investigated the efficacy of COCs coculture and also cumulus-aided embryo transfer on the results of ICSI procedures. We have demonstrated an increase in fertilization and cleavage rates after coculture of oocytes with COCs. Despite an increase in pregnancy rate, a significant difference was not obtained for this parameter.

A previous study, in which Vero epithelial cells derived from Gren monkey kidneys were used as coculture, reported an increased number of blastocytes in coculture groups (10). Another study showed an increase in the implantation rates per embryo in the pregnant patients when the embryos were cocultured with Vero cells (13). Ben-Cherit at al. examined the effect of human embryo coculture with an ovarian cancer cell line (7). They showed that coculture of early cleavage stage human embryos with epithelial cancer cells markedly improved in vitro human blastocyst formation compared with standard culture conditions. Freeman et al. performed a preliminary study to evaluate the effects of granulosa-lutein cell co-culture on human embryo development and pregnancy rates for IVF (11). They demonstrated that autologous granulosa-lutein cell co-culture improved embryo development, implantation and subsequent pregnancy rates for IVF.

Mansour et al. performed a prospective randomized research to study the value of co-culturing human pronucleate oocytes with their cumulus cells (16). They concluded that co-culture of human oocytes with their cumulus cells significantly decreased their fragmentation and increased the number of embryos that reached the 4-cell and 8-cell stages with regular blastomeres. Cumulus cells have been used as a feeder layer in a coculture system in another previous report (6). It was shown that the culture of human embryos with their cumulus cells in insemination drops of medium produced a significantly greater proportion of the fully expanded blastocysts. In a recent report, Kalthur et al. studied the influence of cumulus cell co-culture on sperm motility, and they showed that co-culture with cumulus cells enhanced sperm motility under in vitro conditions (17). As a different condition from our study, cumulus-aided embryo transfer was not performed in these studies. In the present study, the total and mean number of high quality embryos transferred were not improved when cumulus cells were used as a coculture.

A recent study from India was undertaken to evaluate the effect of the use of cumulus coculture and cumulus-aided embryo transfer on pregnancy rates (14). Women undergoing cumulus coculture and cumulus-aided embryo transfer were compared with those who underwent cumulus coculture but did not undergo cumulus-aided embryo transfer. This study demonstrated the efficacy of cumulus-aided embryo transfer, using autologous cumulus cells. However, there was no difference in fertilization rates and cleavage rates in this report between the study and control groups. The results of the study suggested that cumulus cells could play an important role in embryonic development and embryo-uterine adhesion. The present study was not in accord with the results of this report. We obtained significant improvements only in fertilization and cleavage rates in women with cumulus coculture. The number of embryos transferred, implantation and clinical pregnancy rates were similar in the two groups. However, despite the absence of a statistical difference, there was an increased trend towards cumulus-aided embryo transfer for pregnancy rates in our study. This might have resulted from the number of cases in our study.

Cumulus cells accompanying the ovulated oocytes are also capable of secreting many cytokines and growth factors, an ability that may be important in oocyte nourishment and may facilitate embryo cleavage following fertilization (18). Growth factors and cytokines secreted by the cumulus cells are utilized to improve the potential for implantation process. Huang and co-workers reported that the IL system is an important factor in embryo-maternal molecular communication during implantation process (19). Another study has shown that IL-6 secreted by cumulus cells plays a significant role at the time of implantation (20). Parikh et al postulated that the rationale of using the combined technique of cumulus coculture and cumulus-aided embryo transfer was to generate better-quality embryos and to increase the potential for implantation (17). They demonstrated a significant increase in the implantation rate in women undergoing cumulus-aided embryo transfer. In this report, the highorder multiple gestation rates were higher in the cumulus-aided embryo transfer group. Our study did not show any significant increase in implantation rate, but we obtained a trend toward an increase in pregnancy rate in women with cumulus-aided embryo transfer.

In conclusion, the use of cumulus cells as a coculture and the addition of cumulus cells into the uterus may contribute to the effort to improve implantation rates in the future. However, there is only limited data on cumulus coculture and cumulusaided embryo transfer. Further studies with larger series are needed to show the effectiveness of cumulus coculture and cumulus-aided embryo transfer during IVF treatments.

\section{Conflict of interest}

No conflict of interest is declared by authors.

\section{References}

1. Yeung WSB, Ho PC, Lan EYL, Chan STH. Improved development of human embryos in vitro by a human oviductal cell co-culture system. Human Reprod 1992; 7: 1144-9.

2. De los Santos MJ , Mercader A, Francés A, Portolés E, Remohí J , Simón C. Role of endometrial factors in regulating secretion of components of the immunoreactive human embryonic interleukin-1 system during embryonic development. Biol Reprod 1996; 54; 563-74.

3. JayotS, Parneix I, Verdauger S, Discamps G, AudebertA, Emperaire JC. Cocultures of embryos on homologous endometrial cells in patients with repeated failures of implantation. Fertil Steril 1995; 63: 109-14. 
4. Vigano P, Di Blasio AM, Dell'Antonio G, Vignali M. Culture of endometrial cells: a new simple technique to completely separate epithelial glands. Acta Obstet Gynecol Scand 1993; 72: 87-92.

5. Bongso A, Fong CY, Ng SC, Ratnam S. Human embryonic behavior in a sequencial human oviduct-endometrial coculture system. Fertil Steril 1994; 61: 976-8.

6. Quinn P, Margalit R. Beneficial effects of coculture with cumulus cells on blastocyst formation in a prospective trial with supernumerary human embryo. J Assist Reprod Genet 1996; 13: 9-14.

7. Ben Cherit A, J urisicova A, Casper RF. Coculture with ovarian cancer cell enhances human blastocyst formation in vitro. Fertil Steril 1996; 65: 664-6.

8. Bavister BD. Culture of preimplantation embryos: facts and artifacts. Hum Reprod Update 1995; 1: 91-148.

9. Simón C, Mercader A, Garcia-Velasco J, Nikas G, Moreno C, Remohí J, et al. Cocultures of human embryos with autulogous human endometrial epithelial cells in patients with implantation failure. J Clin Endocrinol Metab 1999; 84: 2638-46.

10. Menezo Y, Guerin J F, Czyba J C. Improvement oh human early embryo development in vitro by coculture on monolayers on Vero cells. Biol Rerod 1990; 42: 301-6.

11. Freeman MR, Whitworth CM, Hill GA. Granulosa cell co-culture enhances human embryo development and pregnancy rate following in-vitro fertilization. Human Reprod 1995; 10: 408-14.

12. Bongso A, Soon-Chyne N, Sathananthan H, Lian NP, Rauff M, Ratnam S. Improved quality of human embryos when cocultured with human ampullary cells. Human Reprod 1989; 4: 706-13.
13. Menezo Y, Hazout A, Dumont M, Herbaut N, Nicollet B. Cocultures of embryos on Vero cells and transfer of blastocysts in humans. Hum Reprod 1992; 7: 101-6.

14. Parikh FR, Nadkarni SG, Naik NJ, Naik DJ, Uttamchandani SA. Cumulus coculture and cumulus-aided embryo transfer increases pregnancy rates in patients undergoing in vitro fertilization. Fertil Steril 2006; 86: 839-47.

15. Nottola SA, Heyn R, Camboni A, Correr S, Machiarelli G. Ultrastructural charecteristics of human granulosa cells in a coculture system for in vitro fertilization. Microsc Res Tech 2006; 69: 508-16.

16. Mansour RT, Aboulghar MA, Serour Gl, Abbas AM. Co-culture of human pronucleate oocytes with their cumulus cells. Human Reprod 1994; 9: 1727-9.

17. Kalthur G, Kumar P, Adiga SK. Enhancement in motility of sperm co-incubated cumulus-oocyte comlex (COC) in vitro. Eur J Obstet Gynecol reprod Biol 2009; 145: 167-71.

18. Hill JA. Maternal-embryonic cross-talk. An N Y Acad Sci 2001; 943: $17-25$.

19. Huang HY, Krussel J S, Wen Y, Polan ML. Use of reverse transcription-polymerase chain reaction to detect embryonic interleukin-1 system Messenger RNA in individual preimplantation Mouse embryos co-cultured with veto cells. Human Reprod 1997; 12: 1537-44.

20. Tabibzade S, Kong QF, Babaknia A, May LT. Progressive rise in the expression of interleukin-6 in human endometrium during menstrual cycle is initiated during the implantation window. Human Reprod 1995; 10: 2793-9. 